\title{
Virtualioji Lietuvos spaudos biblioteka - patirties pamokos naujų iššūkių akivaizdoje
}

\author{
Silvija VÉLAVIČIENÉ
}

Lietuvos nacionalinè Martyno Mažvydo biblioteka, Gedimino pr. 51, LT-01504 Vilnius, el. p. s.velaviciene@Inb.lt

Nelengva susivokti, kas yra ivykę per tą laiką, kai pradèta skaitmeninti lietuviškoji spauda, kai mums iprastı̨ popierinių šaltiniụ pažinimas palengva keliasi i virtualią erdvę, iš esmés keisdamas nusistovejusius informacijos teikimo būdus ir kaskart vis labiau plèsdamas jụ naudojimo galimybes bei priartindamas prie vartotojo. Toki vyksmą galètume drąsiai ivardinti kaip lemtingą lūži visoje Lietuvos biblioteku informacinejje sistemoje, kad ir pirmais nelabai drąsiais žingsniais, tačiau palengva artinantị mus prie šioje sferoje kur kas anksčiau pradejjusių dirbti ir daug didesnę patirti turinčiu šalių. Ne tik Lietuvos, bet ir užsienio vartotojams vis plačiau veriamos durys i nacionalinès spaudos lobynus, tačiau naujoji veiklos sfera jpareigoja ir didžiulei atsakomybei, kuri gula ant pirmeivių pečių. Neisvengiamai artėja laikas, kai teks labai rimtai aptarti, kaip virtualiosios Lietuvos spaudos bibliotekos kūrimas paveiks ir keis kai kuriuos iprastinius bibliografinès informacijos priemonių rengimo būdus ar squveikaus su jais, ir apsispręsti, ar prieš daugelị metı numatyta bibliografinių leidinių rengimo tvarka ir chronologinè eilé nauju technologijų suteiktu galimybiu akivaizđoje turẻtu likti tokia pati.

Tačiau bene didžiausias rūpestis Lietuvos spaudos virtualios bibliotekos kūrimo procese bus finansinès galimybẻs ir visu Lietuvos spaudos turtus saugančiu instituciju sutarimas dèl pamatinès idejjos, nulemsiančios galutini apsisprendimą dèl kuriamo objekto pilnatvès, jo apimties, chronologiniu ribu, informacijos pateikimo gilumo. Toks dokumentas, skirtas aptarimui, smulkiai viso proceso veiksmu analizei, turètu tiksliai apibréžti visų dalyvaujančiu instituciju pareigas bei atsakomybę, kuo tiksliau nurodyti prioritetus, darbu eilès tvarką, suformuluoti ypač aiškius atrankos kriterijus. Akivaizdu, kad Lietuvos visuomenè ir užsienio vartotojai gali tiketis iš rengejjų fundamentalios ir visa apimančios visos Lietuvos spaudos virtualiosios bibliotekos sukūrimo idéjos, o ne atskirų institucijų bibliotekose saugomı̨ suskaitmenintų spaudos vienetu katalogų. Iškyla koordinacijos ir bendru sprendimų būtinybè, idant taupant lèšas bendru sutarimu būtu siekiama norimo rezultato. Toki atskirą dokumenta, skirtą vien tik Lietuvos spaudos skaitmeninimo uždaviniams apibréžti, su išsamia viso proceso konkrečiu veiksmu išklotine, su tvirtu visı dalyvaujančių institucijų pareigu bei atsakomybès apibréžimu, aiškiı atrankos kriteriju, prioritetų bei darbų eiliškumo nuostatomis galètu rengti Lietuvos Respublikos kultūros ministerijos sudaryta paveldo skaitmeninimo taryba, sutelkusi bendram tikslut visas Lietuvos spaudos paveldq saugančias institucijas, kurios privalètų smulkiai aptarti daugybę aktualių klausimu̧, neatsakytu vykdant pirmaji Virtualiosios bibliotekos kūrimo etapa. Remiantis vien tik išsamumo nuostata ir pasikliaujant Lietuvos nacionalinés bibliografijos duomenimis bei atrenkančiuju asmenų kartais subjektyvia nuomone, i skaitmeninamų objektụ sąrašus pakliūva ir mažesnès ar net menkos reikšmés Lietuvos spaudiniai. Tokia nuostata visai pateisinama senosios Lietuvos spaudos (būtent knygu) atžvilgiu, tačiau artinantis prie naujuju laiku ji neabejotinai turès keistis - čia jau pagrindiniu atrankos principu, manyčiau, turètų tapti tik leidinio verté, antraip Lietuvos kultūrai ypač svarbūs leidiniai gali paskęsti menkesnių ir šiandien mus tik kaip spaudos istorijos faktas dominančiu knygu skaitmeninių kopijų jūroje. Būtent todèl turètų būti parengtos labai aiškios atrankos taisyklès. Sudarant jas, be jokios abejonès, labai svarbus tebèra ir atrankos bei pirmumo eilès nustatymo kriterijụ pasirinkimas. Žinoma, diskutuotinas ir absoliučios pilnatvès principas, tačiau turint galvoje, kad skaitmeninių kopiju gamyba yra ganètinai brangus procesas, tokią nuostatą vertẻtų palikti ateičiai, kai virtualiojoje Lietuvos spaudos bibliotekoje vertybiniu principu jau bus sukauptos pačios svarbiausios, išliekamosios vertés knygos. Tada - tikètina - ir valstybè bus turtingesnè, ir skaitmeninimo technologijos ne tokios brangios. Nacionalinė bibliografija yra tvirtas pamatas rengiant virtualiają biblioteka, tačiau tai neturètu būti tapatinami dalykai.

Svarbiausia pirmojo etapo patirties pamoka yra ta, kad patikimesnio rezultato galima siekti tik sutelktomis jvairił institucijų jégomis. Geriausiu tokio teiginio pavyzdžiu galètı̨ 
būti bene pati sẻkmingiausia darbų daliss - Lietuvos periodines spaudos (nuo 1918 iki 1940 metu) skaitmeninimas, Šio darbo pagrindas buvo didžiuju Lietuvos bibliotekų bendromis jègomis parengtų lieนuviškụ periodiniu leidiniu mikrofilmu rinkinys, pagamintas po kruopelytę renkant medžiagą iš visų biblioteku fondu. Todè] ir skaitmeninè šiu periodinių lejdinių biblioteka bus nepaprastai vertinga - jei joje atsispindès visi leidiniai, kurie šiuo metu yra saugomi Lietuvos bibliotekose. Kol kas, deja, dar yra nemažai spragu, kurios gali klaidinti vartotoją. Turint galvoje, kad ligi šiol tebèra nebibliografuotas labai svarbus lietuviškos periodinès spaudos laikotarpis nuo $1918 \mathrm{iki}$ 1940 metụ (jei neminèsime kai kuriụ pasirinktinai Vaclovo Biržiškos „Bibliografijos žiniose“ atspindètu straipsniu), kuo spartesnis virtualiosios periodiniu leidinių bibliotekos sukūrimas turi neikainojamą vertę ir dèl to, kad iš dalies atstoja bibliografiją ir - bene svarbiausias faktorius apsaugo trapius, nuo begalinio vartymo ant sunykimo ribos atsidūrusius periodiniu leidinių (ypač didžiojo formato) komplektus. Taigi skaitmeninės senuju spaudiniц kopijos padeda spręsti ne tik informacijos pricinamumo, bet ir spaudiniu apsaugos problema.

Labai svarbi yra ir kita Lietuvos spaudos virtualiosios bibliotekos kūrimo turinio problema, kuri ligi šiol nèra giliai išanalizuota ir aptarta, todèl neturime ir galutinio sprendimo - tai visos Lietuvos kitakalbès knygos. Istorinès aplinkybès lémè, kad Lietuvos Didz̃iosios Kunigaikštystẻs, po to bendros Lietuvos ir Lenkijos valstybés laiku spauda, o véliau ir Lietuvos spauda jau esant Rusijos imperijos sudètyje yra tapusi ne tik Lietuvos, bet ir kitu valstybiu nacionalinès bibliografijos objektu. Geriausias pavyzdys garsioji Lenkijos spaudos, vadinamoji Ostreicherio, bibliografija, kurioje rasime ir Lietuvos kitakalbius leidinius. Todèl renkantis skaitmeninimo objektus neišvengiamai teks kaupti informacija apie tai, ar jie nèra jau pateikti virtualiojoje erdveje kitos šalies pastangomis, ir derinti veiksmus su Lenkijos, Rusijos, Vokietijos, Baltarusijos institucijomis.

Dar kebliau bus atsirinkti skaitmeninimui ne Lietuvoje spausdintus, tačiau su ja susijusius lituanikos leidinius. Be jokios abejonès, mūsų virtualiają biblioteką papuoštų ir labai svarbios informacijos apie Lietuvos istoriją tyrinètojams suteikty tokie leidiniai, kaip Motiejaus Strijkovsio ar Jano Bielskio „Kronikos", išspausdintos XVII amžiuje, ar pirmoji atskira knyga išleista Alberto Vijūko Kojalavičjaus dvitomé "Lietuvos istorija" lotynu kalba, išspausdinta Dancige ir Antverpene 1650 ir 1669 metais, tačiau minètụ leidiniц atspindéjimas virtualioje erdvèje taip pat pareikalaus gerai apgalvotų ir pagristu sprendimu.

Virtualioji biblioteka nepaiso valstybių sienų bei atstumu, ji netruks peržengti ir Europos ribı̨, nes mūsų valstybès istorijos kai kurie laikotarpiai (ypač spaudos draudimas 1864-1904 metais) buvo itin nepalankūs lietuviškosios spaudos raidai tévynèje. Didžioji dalis to laikotarpio lietuviškų knygų ir periodinių leidinių spausdinta už Lietuvos ribu - Mažojoje Lietuvoje ir Jungtinèse Amerikos Valstijose. Lietuvos bibliotekose nėra išsamiu XIX ir XX amžiaus pradžios lietuvišku periodinių leidinių komplektų. Šių leidinių paieškos nuveda ir i Europos, ir i JAV bibliotekas, skatina labai svarbiems darbams - remiant tokioms institucijoms, kajp JAV Kongreso biblioteka, Čikagos mokslinè biblioteka, Rusijos nacionalinė biblioteka Sankt Peterburge, taip pat lietuvių išeivijos kultūrinèms organizacijoms, pagaliau sukaupti visą užsienyje spausdintų lietuviškų leidinių rinkini. Geriausias pavyzdys - leidybos šimtmečio sukaktį 2009 metais minintis ir dabar Čikagoje tebespausdinamas lietuviškas dienraštis „,Draugas“", kurio, ypač pirmujų metı̧, Lietuvos bibliotekose saugome tik pabiras. Turima žinių, kad „Draugo" redakcijoje saugomo ankstesniụ metu archyvo mikrofilmavimu susidoméjo ir JAV gyvenančiç tautu kultūrinio palikimo išsaugojimu besirūpinančios tos šalies institucijos. JAV valstybinèse bei ivvairių universitetu bibliotekose yra sukaupta nemaža mums rūpimos anapus Atlanto spausdintos senosios lietuviškosios periodinès spaudos mikrofilmu, nes tame krašte jau seniai siekiama vietoj nepatogị saugoti ir dẻl prasto popieriaus byrančių laikraščių komplektų turèti tik jų mikroformas. Daugiausia žinių apie Lietuvoje ir už jos ribų išsaugotus lietuviškus periodinius leidinius ar ju mikroformas sukaupta buvusių Knygu rūmu (dabar - Lietuvos nacionalinès Martyno Mažvydo bibliotekos Bibliografijos ir knygotyros centro) parengtuose kontroliniuose sąrašuose, tačiau jie parengti prieš du dešimtmečius, o kasdien atsiranda vis daugiau naujos informacijos, kurią būtina nuolatos sekti bei fiksuoti. Tokios informacijos paieškai ypač padeda internete prieinami ¡̣vairiı̨ šaliụ bibliotekų elektroniniai katalogai, tačiau neapgalvotai ieškant prarandama ypač daug laiko. Šioje srityje darbu tęstinumas ir gebejjimas panaudoti visas ligi šiol sukauptas žinias yra pagrindinè sẻkmès sąlyga.

Taigi šaltinių paieška ir atranka yra svarbiausias Lietuvos spaudos virtualiosios bibliotekos kūrimo uždavinys, nuo kurio sèkmés priklausys ir galutinis rezultatas. Tiksli informacija apie kituose kraštuose (ar Lietuvoje - pvz.: Pranciškonų vienuolijos rūpesčiu virtualioje erdvèje jau prieinamas išeivijos kultūros žurnalas, ,Aidaij) jau suskaitmenintus leidinius ar saugomus trūkstamı šaltinių mikrofilmus, padés išspręsti ir daugybę gretutinių problemu̧, tačiau tam reikès nemažai laiko deryboms ir ženklių finansinị sąnaudụ.

Didžiausi iššūkiai visuotinès virtualiosios Lietuvos spaudos bibliotekos kūrẻjams yra griežti reikalavimai paisyti dabar galiojančiı Lietuvos ir užsienio autoriu ar leidèjụ teises ginančiu istatymu, reglamentuojančių spaudiniu naudojimo ir sklaidos galimybes. Ypač daug keblumų ir nesusipratimų kyla dè chronologinių ribų apibréžimo tick knygoms, tiek periodiniams leidiniams. Daugeliu atveju nęmanoma surasti prieš 50 metụ išeivijoje spausdintu 
laikrašc̆iu ar žurnalu teisių perèmejju o to reikalaujama jstatyme. Nebėra nei leidejjais buvusių organizaciju, nei daugelio atsakingu asmenu. Paisant tokiu reikalavimu daugelio lietuvių išeivijos periodinių leidinių skaitmeninimas atsiduria aklavietejje. Todẻl nebus imanoma išspręsti problemos be kai kuriı jstatymu ir nuostatı keitimo.

Ypatingo pagyros žodžio virtualiosios bibliotekos kūrẻjai nusipelno už pastangas užpildyti XVI amžiaus senosios lietuviškos spaudos spragas nors virtualiojoje erdvèje. XVI amžiuje turèjome tik I 6 lietuviškų knygu, iš kurių Lietuvos bibliotekose saugomi vos pusés - aštuonių knygụ originalai. Šie leidiniai, neretai vadinami lietuviu kalbos paminklais, yra ypač svarbūs gausiems lietuviu kalbos tyrinètojams visame pasaulyje, todél ju tekstai virtualiojoje erdvèje suteikia neribotas galimybes tyrinèti vieną seniausił indoeuropiečių kalbụ, išsaugojusių archaiškiausias grama- tines formas. Tai, kad virtualiosios Lietuvos spaudos bibliotekos kūrẻjai rūpinasi šešių Lenkijos, Vokietijos bei Švedijos bibliotekose saugomų unikaliu XVI amžiaus lietuviškų knygu skaitmeninemis kopijomis ir bando užpildyti šią spraga, teikia vilčiu, kad ir ateityje nepristigs nei noro, nei jëgц nuoseklioms šaltinių paieškoms. Tai, ko nebuvo imanoma padaryti anksčiau, - ir dël istorinių ir dèl techninių galimybius - tikèkime, bus padaryta dabar sukūrus visavertę Lietuvos spaudos virtualiają biblioteka, padẻsiančią ne tik išspręsti daugybę susikaupusių problemų, bet ir pagaliau surinkti virtualiojoje erdveje visus Lietuvoje sukauptus bei užsienyje atrastus trūkstamus šaltinius, suteikti vartotojams patrauklias, šiuolaikiškas galimybes naudoti Lietuvos spaudoje per beveik penketą šimtmečiu sukaupta intelektini turta, kartu - apsaugoti trapius popierinius leidinius nuo sunykimo. 